\title{
自動空気排除装置を用いた長距離サイホン管における水理性能の現地検証
}

\author{
高橋研二 ${ }^{1} \cdot$ 小倉邦雄 ${ }^{2} \cdot$ 稲垣仁根 $^{3}$
}

\section{Field Verification of Hydraulic Performance in Long-distance Siphon Pipe using Automatic Air Evacuation System}

\author{
Kenji Takahashi $^{1}$, Kunio Ogura ${ }^{2}$ and Hitone Inagaki ${ }^{3}$
}

\begin{abstract}
Using a siphon to transfer water along a dike out of a reservoir is an extremely economical water intake method. However, because the pressure at the top of the siphon is less than atmospheric pressure, air released from the water collects at the top. The accumulation of air reduces the pipeline's capacity to transport water. In the worst case scenario, the water flow in the siphon stops completely. Therefore, a new automatic air evacuation system to remove air from the siphon pipe that does not use the safety flow pump was developed.

In pipeline systems connected with 5 irrigation reservoirs in the $\mathrm{M}$ irrigation project of Okinawa Prefecture, siphon pipe systems equipped with automatic air evacuation were used. Through the use of this system, the pressure in the long distance siphon pipes decreased, and as a result, the system was unable to maintain a consistent flow. Measurement instruments including a pressure gauge and a flow meter installed in the system verified hydraulic performance in long distance pipes that were using automatic air evacuation. The results revealed that when the equipment was operating normally, the siphon flow formed temporarily, but over time the siphon flow degraded and finally ceased. It is hypothesized that the cause of this is related to the longitudinal profile design of the long distance pipes. Important points to consider in the design of future siphon pipe systems that are equipped with automatic air evacuation are discussed.
\end{abstract}

Keywords: Automatic air evaculation system; Long-distance siphon pipe; Pump; Irrigation reservoir; Hydraulic performance; Field verification

\section{1 はじめに}

全国には約 21 万力所のため池があり，その約 $75 \%$ は築 造後100年以上を経過し, 老朽化が原因で堤体や取水 施設の改修を必要としているものが多数存在する。ため 池における取水は一般に斜樋や取水塔で行われ, 堤体 の底樋管から堤外に導水されている。これら取水施設 の改修を行う場合は，堤体を掘削してパイプを布設替え するなど大規模な工事となり，多額の工事費を必要とし ている。

堤体に関わる改修工事を回避する方法として, 堤防 の上をサイホン管で越える方式がある。このサイホン管 方式は，揚水ポンプを使用する方法に比べて，施設費 と電気料金が安価であり,きわめて経済的な方法である. しかし，通水時にはサイホンの頂部が負圧となるため， 空気が逸出して, 頂部に空気塊が停留し，これが通水 を阻害することが課題となっており，本方式の普及を妨 げる要因となっていた。そこで，姜ら(1994a,1994b)は， 通常の家庭用ポンプを用いたサイホン管内自動空気排

${ }^{1}$ (株) 横田製作所技師, Engineer, Yokota Manufacturing CO., LTD, 1-3-6 Minamiyoshijima, Naka-ku, Hiroshima 730-0826, Japan

2 (株) 横田製作所元技術部長, Former Chief Engineer, Yokota Manufacturing CO., LTD, 1-3-6 Minamiyoshijima, Naka-ku, Hiroshima 730-0826, Japan

3 宮崎大学農学部教授, Professor, Faculty of Agriculture, University of Miyazaki, 1-1 Gakuen Kibanadai-nishi, Miyazaki 889-2192, Japan (Corresponding Author) E-mail:a03221u@cc.miyazaki-u.ac.jp
除装置を開発し，サイホンにおける空気逸出量や装置を 構成する要素の諸元と空気排除体積の関係について, 詳細な実験を行って, 設計の基礎資料を示した。

このサイホン管内自動空気排除装置を設置することに より，ポンプにより自動で空気排除を行いながら，通水 能力を維持することが可能となり，香川県において，た め池からの取水方式として, 先端的に採用されている(西 山, 2000).

沖縄県南大東島のM地区においては，地区内に点在 する5 ケ所の貯水池を畑地灌溉の水源とし, 各貯水池の 間は, 自動空気排除装置を装備したサイホン管により接 続している. 最終的に，4力所の貯水池の水源水は，一 力所の貯水池に集められ，揚水ポンプによりファームポ ンドまで圧送され, 一旦貯留された後, 自然圧式パイプ ラインで受益地区に配水する畑地灌溉システムとなって いる.

当該地区において，ため池間を結ぶサイホン管の実 運用を開始したところ, 送水開始時には充水により満水 状態を確保しているが, サイホン管が長距離となる場合, 通水開始後に圧力が低下し， サイホン現象が短時間で 維持できなくなる現象が，繰り返して発生した。対応策 としては, 再充水を行い, 灌溉システムの稼働の維持 を図っていたが，再充水に多大な時間と労力が必要な 割に，通水時間が極端に短いため，システムの運用に 支障を来していた。

著者らは，本地区の自動空気排除装置を装備したサ 
イホン管に圧力計や流量計などの計測機器を設置して, 機能検証を行った。本報では, サイホン管が水理的に 機能しない原因を探り, 今後のサイホン管の設計への対 策を検討した結果を報告する。

\section{2 畑地灌溉システム}

\section{1 パイプラインの概要}

本地区の畑地潅溉システムは, 図 1 の平面図に示すよ うに4力所の貯水池を自動空気排除装置 (封水装置) を 装備したサイホン管で結び, 各貯水池の貯留水を3-1号 貯水池に集め, ポンプでファームポンドに送水して, 受 益地区へ配水するシステムになっている.

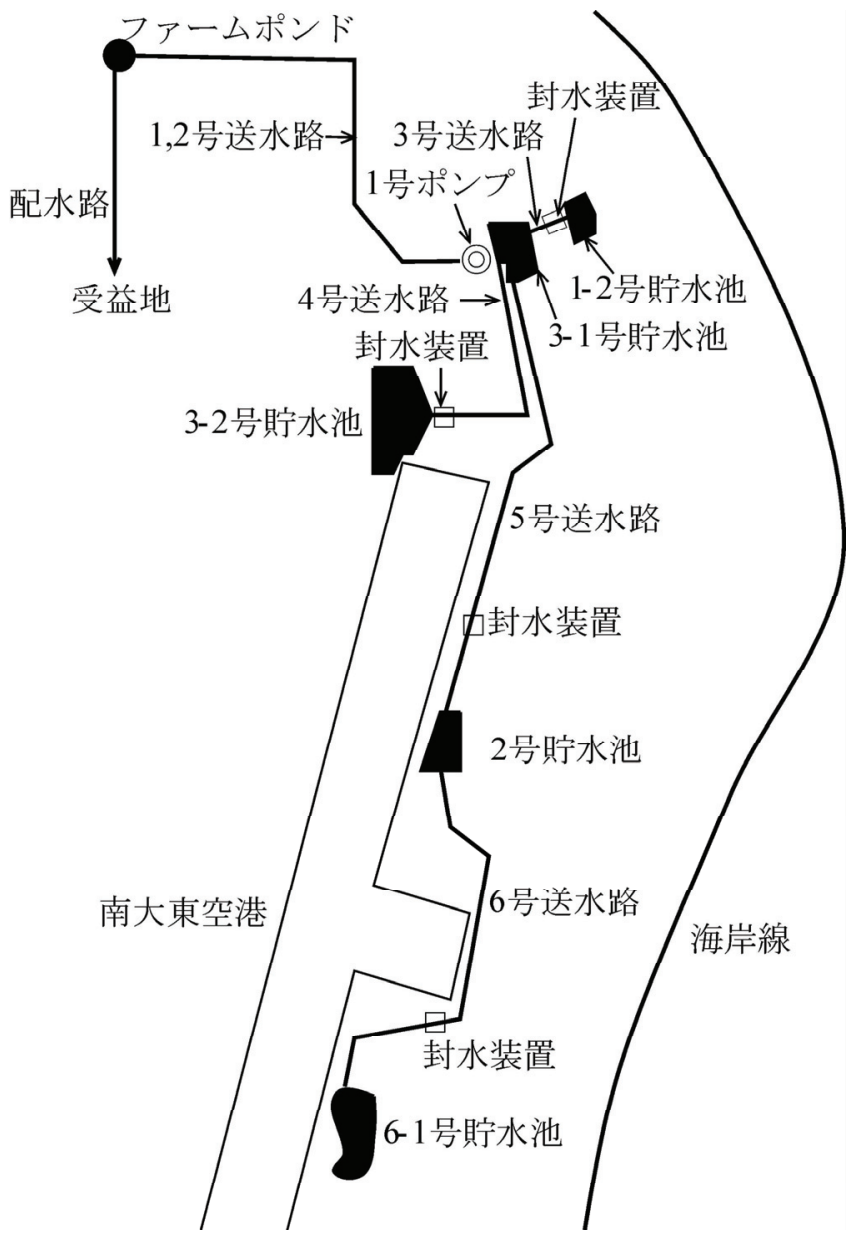

図 1: 畑地潅溉システムの概要図

また，各調整池，封水装置および送水路の標高を図 2 の縦断図に示す。縦断図には, 各貯水池のLWLを始点 とする動水位を示し，さらに，この動水位と送水路の中 心高との差 (負圧) を示す. 貯水池がLWLで計画流量 が流下する場合は, サイホン管の全体で最大 $9 \mathrm{~m}$ に達す る負圧が発生する。サイホン始点には, 貯水池の水位 変化に対応して取水するために，フロート式の取水装置

(写真 1 ) を設置した。また, 封水装置（写真 2) は 各サイホン管において最も標高の高い地点に設置した。 さらに，通水時には，送水路末端（写真 4) の貯水池 流入点に設置した調整弁（写真 3 ) を操作して, サイ ホンの流れを制御している。
サイホン管（送水路）の諸元を表 1 に, 貯水池の諸 元を表 2に示す.

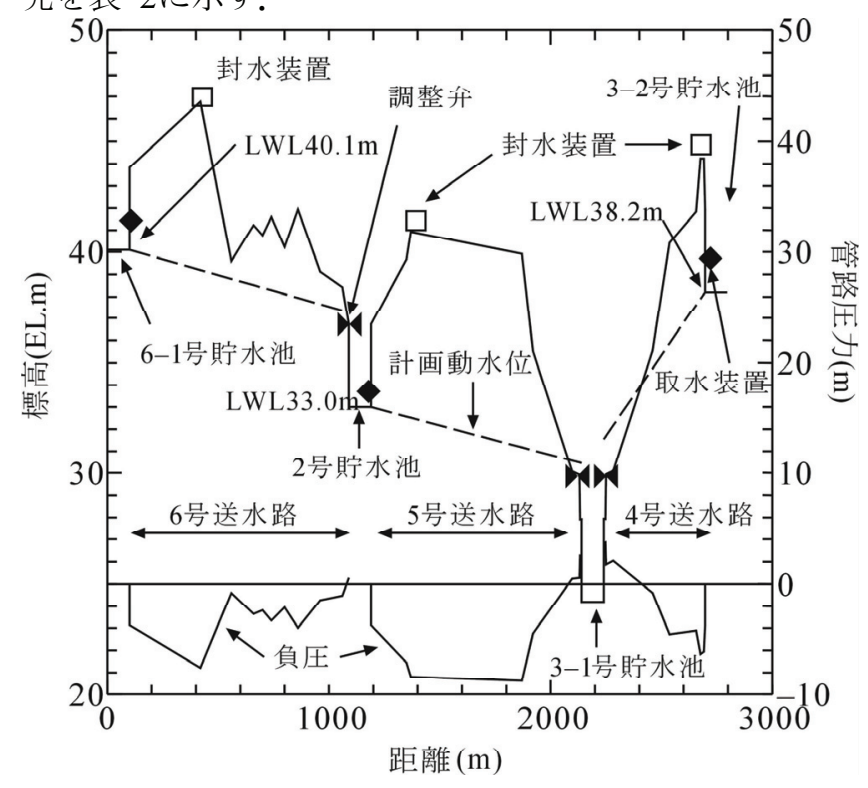

困 2: 貯水池間送水管の縦断図

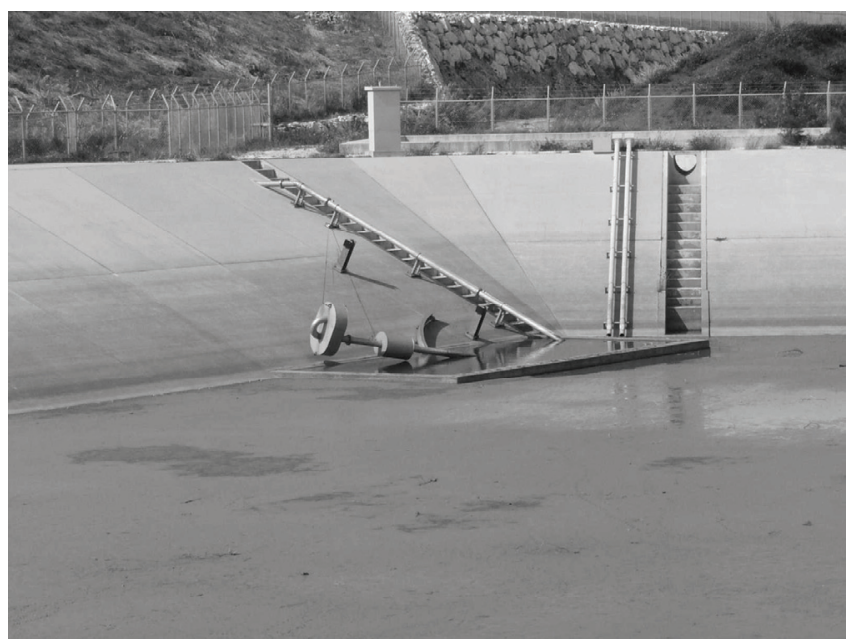

写真 1 : 取水装置

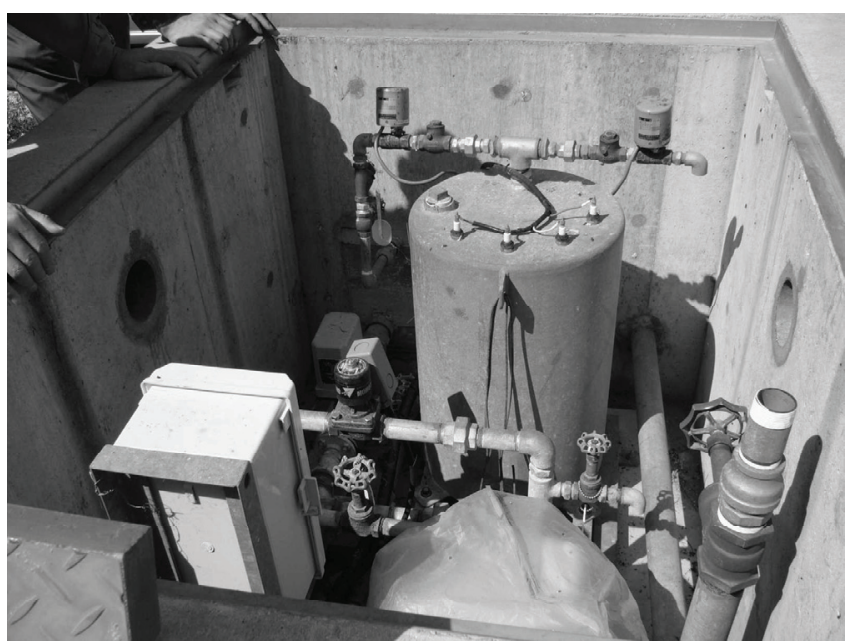

写真 2: 封水装置 


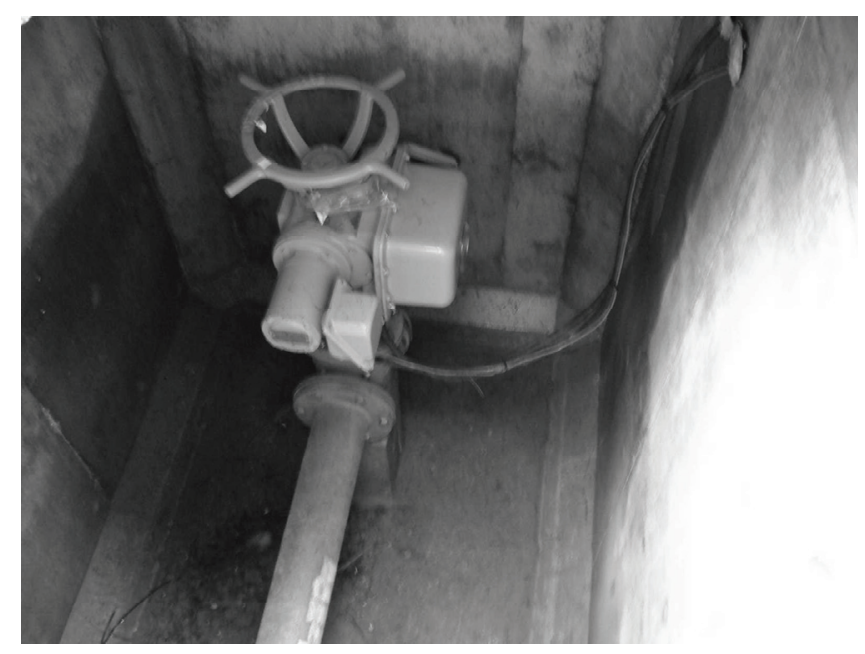

写真 3: 調整弁

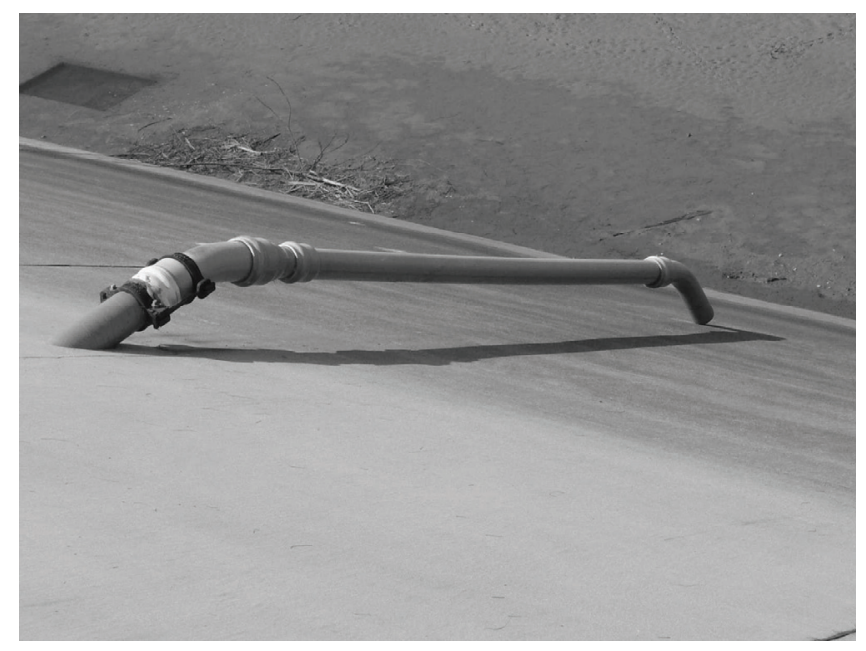

写真 4: 送水路末端

表 1 : 送水路の諸元

\begin{tabular}{cc|c|c|c|c|c}
\hline 項 & 目 & 単位 & 3 号 & 4 号 & 5 号 & 6 号 \\
\hline 流 & 量 & $\mathrm{L} / \mathrm{s}$ & 3.6 & 8.8 & 10.2 & 6.5 \\
\hline 内 & 径 & $\mathrm{mm}$ & 75 & 100 & 150 & 125 \\
\hline 延 長 & $\mathrm{m}$ & 80.0 & 453.0 & 950.0 & 990.0 \\
\hline 管 種 & & VU管 & VU管 & VU管 & VU管 \\
\hline 封水装置 & EL.m & 32.96 & 44.24 & 40.92 & 46.76 \\
\hline
\end{tabular}

表 2: 貯水池の諸元

\begin{tabular}{l|c|c|c|c|c|c}
\hline 項 目 & 単位 & $3-1$ 号 & $1-2$ 号 & $3-2$ 号 & 2号 & 6-1号 \\
\hline LWL & EL.m & 24.20 & 29.25 & 38.20 & 33.00 & 40.10 \\
\hline HWL & EL.m & 28.20 & 33.20 & 42.20 & 37.00 & 44.10 \\
\hline 容量 & $\mathrm{m}^{3}$ & 26,419 & 16,561 & 39,864 & 16,561 & 29,279 \\
\hline
\end{tabular}

\section{2 封水装置の概要}

サイホンに設置した自動空気排除装置（封水装置）の 概要を図 3 に示す。この封水装置は, 通常の家庭用ポ ンプ, 給水管, 注水管, 排気管, 電動弁 4 個, 水位セ ンサー，自動制御装置から構成されている。各連結管 の組み合わせは以下のようになっている。

(1)給水タンクとサイホン管 : 電動注水弁と注水管および 電動排気弁2と排気管
(2)給水ポンプと給水タンク：電動給水弁と給水管 (3)給水タンクと大気空間 : 電動排気弁 1 と排気管

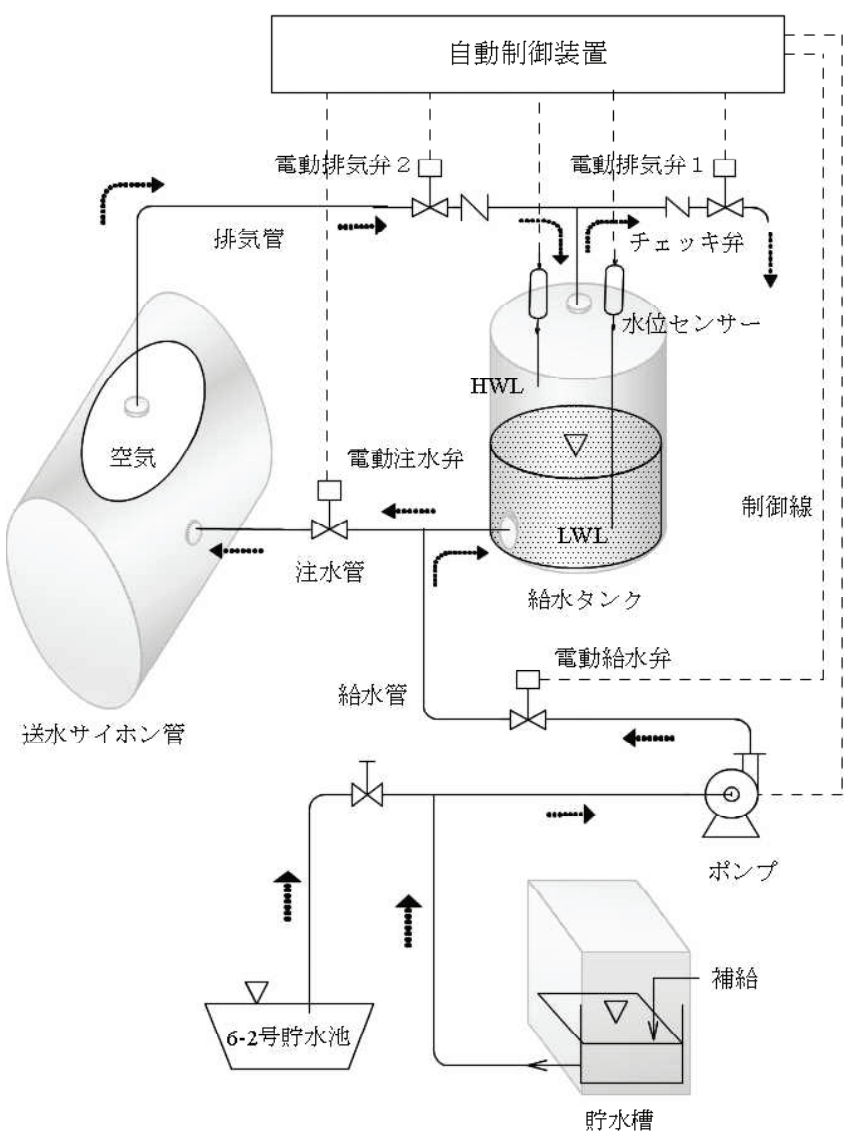

困 3: 封水装置の概要

電動弁は，自動制御装置の制御によって作動させ， 給水ポンプも自動制御装置の制御によって自動的に作 動する仕組みとなっている。なお，給水ポンプの水源は， ため池であるが，6号送水路については，封水装置に併 設した貯水槽からの給水も併用している。

この装置による空気排除原理は, 給水タンク内の水 の重力によってサイホン管内の空気を置換することであ り，以下のような作動順序となる.

(1)電動給水弁と電動排気弁1が同時に開き, 給水ポンプ が作動して, 給水管を通じて給水タンク内へ給水し始 める.

(2)給水タンク内の空気は排気管を通じて大気中に放出 される。

(3)給水タンク内の水位がHWLまで上昇すると, 自動制 御装置の制御によって電動給水弁と電動排気弁1が閉 鎖され, 給水ポンプの作動が停止し, 給水タンク内空 気の大気中への放出も終了する.

(4)電動注水弁と排気弁2が開き, 給水タンクは注水管と 排気管によってサイホン管と連続する.

(5)注水弁と排気弁 2 が開き, 給水タンク内の水は重力に より注水管を通じてサイホン管内に流入する.

6)サイホン管内に蓄積した空気は，浮力によって排気管 を通じて給水タンク内へ流入する。

(7)給水タンク内の水とサイホン管内空気が置換される.

8給水タンクの水位が徐々に低くなって, LWLまで達す 
ると, 自動制御装置の制御により電動注水弁と排気 弁2が閉鎖する.

サイホン管内空気が全部排除され，サイホン管内が満 水状態になるまで，(1)〜8の過程を自動的に繰り返す.

\section{3 サイホン管の現状と課題}

\section{1 通水の状況}

6号送水路については，通常は2〜3時間でサイホンが切 断され，これまでの実績でサイホンが形成された最長の 時間は，約5時間ぐらいである。ささらに，5号送水路につ いては，サイホン現象は全く形成できない結果となって いる。 また，4号送水路については，縦断線形が一山で あり, 延長も短く, 封水装置は吸い込み側の3-2号調整 池に近接しており, サイホン現象は容易に形成でき, 切 断もなく運用には支障は生じていない。

\section{2 充水の状況}

通水開始前にサイホン管を満水にするために, 始点の 取水装置と末端の調整弁を閉鎖して, 充水作業を行う 必要がある。封水装置は, 通水中にサイホン内で発生 する空気を, 給水タンク（容量 80 リットル）の水で置き 換える装置であるが, 給水タンクの容量は, 初期充水に 必要な水量に不足する。そこで，写真 5に示すように， 送水路の途中の空気孔からタンク車で充水しているが, 作業が非常に困難であり, 人員を 2 ～ 3 人, 作業時間と して4〜5時間を要するため, マンパワーの極めて少ない 島嶼地域において, 充水作業の負担が大きくなっている.

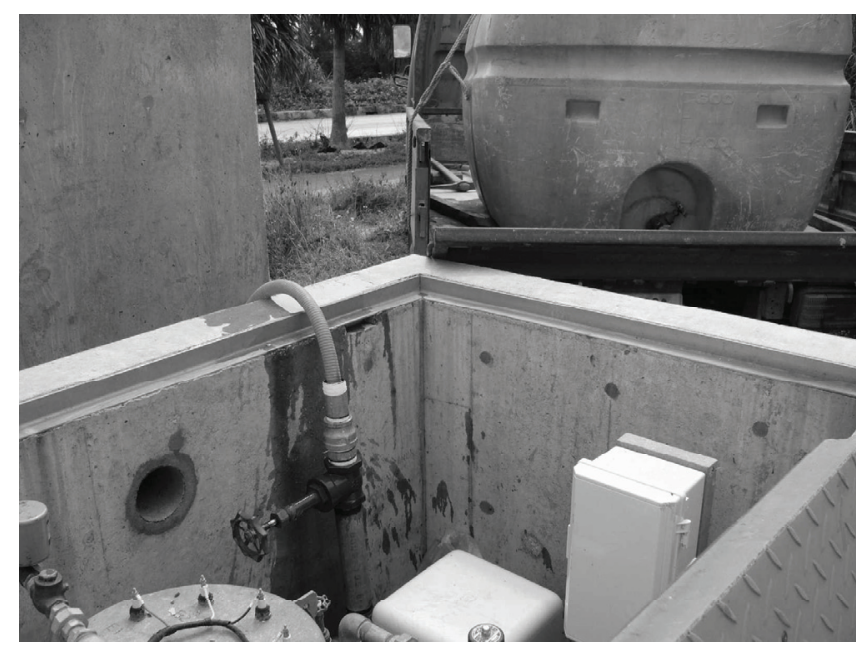

写真 5: 空気孔からの充水作業

このような充水作業によっても, サイホン内の空気を 完全に排出することができないため, サイホンの形成に 障害となっている。そこで，6号送水路では，充水作業 を軽減するために, 図 3 に示すように封水装置の横にス タンドを設置して，畑かん用水ラインから水を確保し， 水位差により注水できるようにしている。しかし, サイホ ン現象が通水開始後に短時間で切断されるため, サイ ホン管への充水作業を繰り返す必要があり, 畑地潅溉シ ステムの維持管理に支障を来している。また，サイホン 管の途中に制水弁がないことも，充水作業を困難にし ている要因となっている。

\section{4 実験施設および実験内容}

\section{1 実験施設}

サイホン管におけるサイホン現象の生成と崩壊について の現地試験は，サイホン現象が一時的に形成できる6号 送水路を対象とした。 6-1号貯水池の取水装置について は, 貯水池の水位が常時低く, 充水や初期通水に使用 できないので，VU管を送水路から分岐させて，堤体に 露出配管し (写真 6), 始点に流入弁 (写真 7) を設 置した.この流入弁を充水時には閉鎖し，初期通水時 には全開操作した。

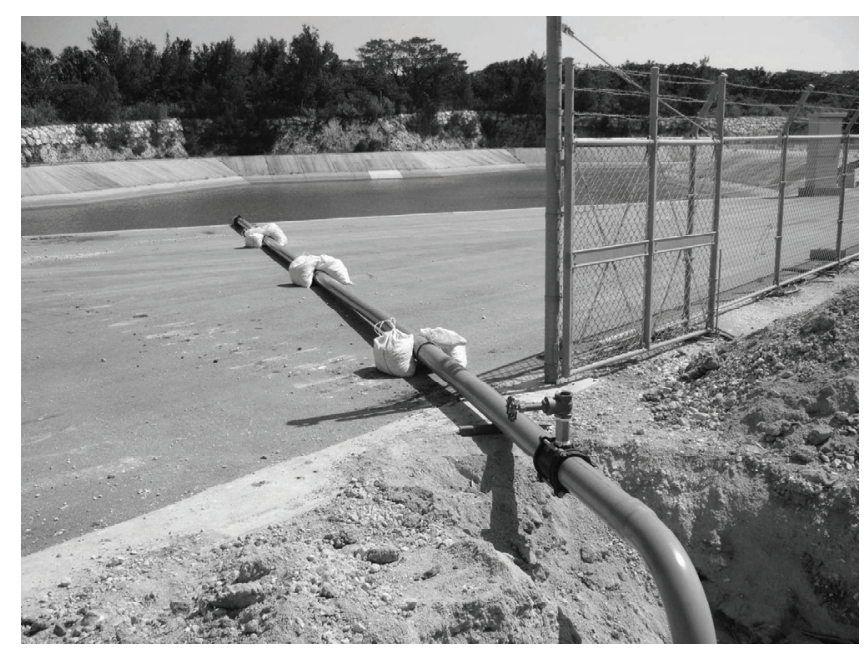

写真 6: 6号送水路バイパス管(6-1号貯水池)

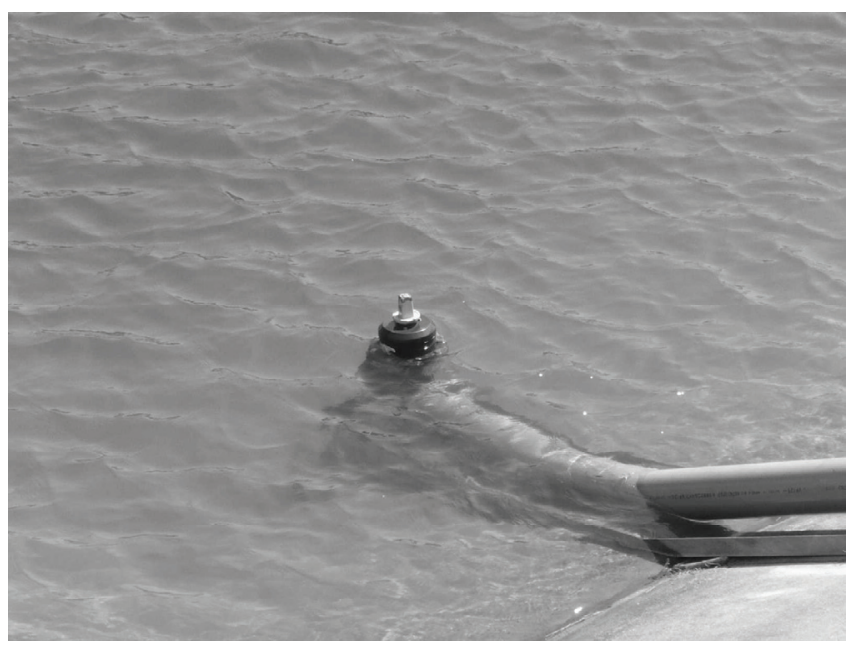

写真 7: 流入弁 $(6-1$ 号貯水池)

\section{2 計測装置}

図 4に計測装置の設置位置を示す。管路の圧力を計測 する圧力トランスミッタKH-15 (長野計器) を, 封水装 置内の空気孔に設置し (写真 8), ADコンバータでア ナログ・デジタル変換を行い，パソコンに記録した。さ らに，6-1号貯水池から780m下流と末端の調整弁の直 上流（始点から935mの地点）にある空気弁に, 圧力卜 ランスミッタを設置して(写真 9), 圧力の計測を行った. また，写真 10 に示すように，ポータブル超音波流量計 UFP-20 (東京計器) を6号送水路始点（6-1号貯水池） 
に設置し，流量を計測した。

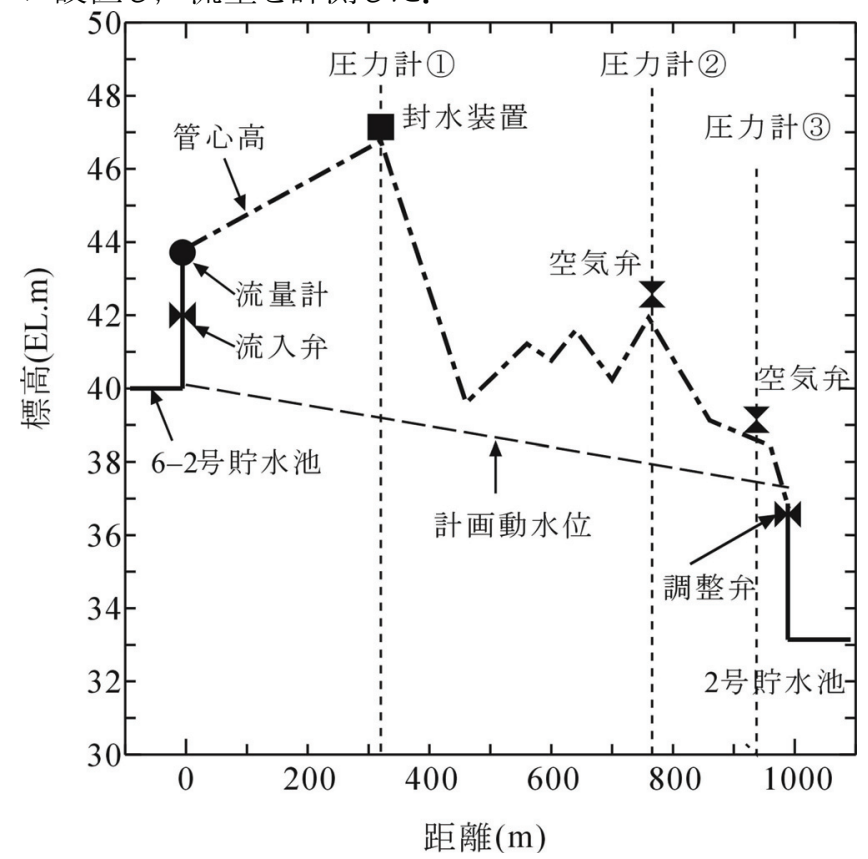

図 4: 計測装置の配置

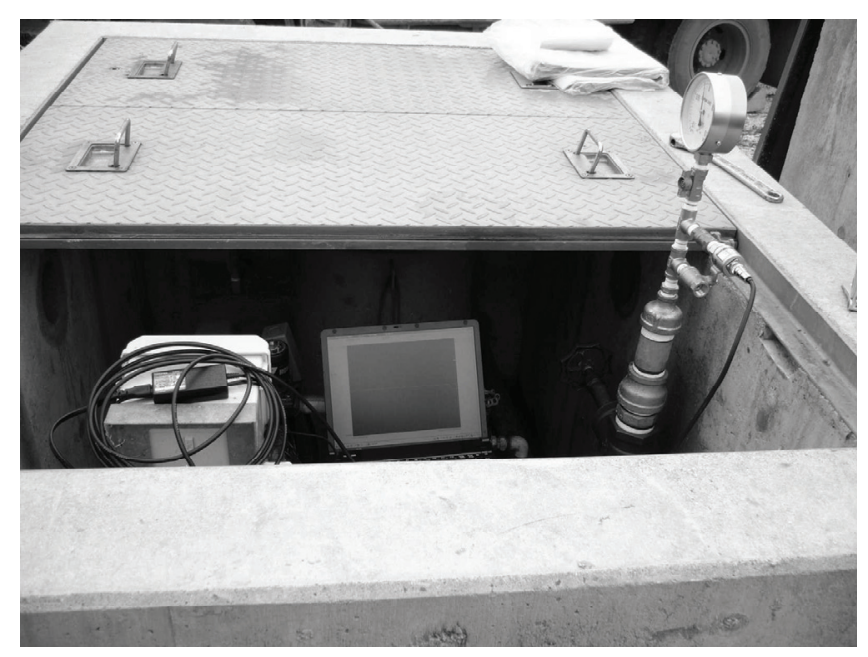

写真 8: 圧力計測(封水装置)

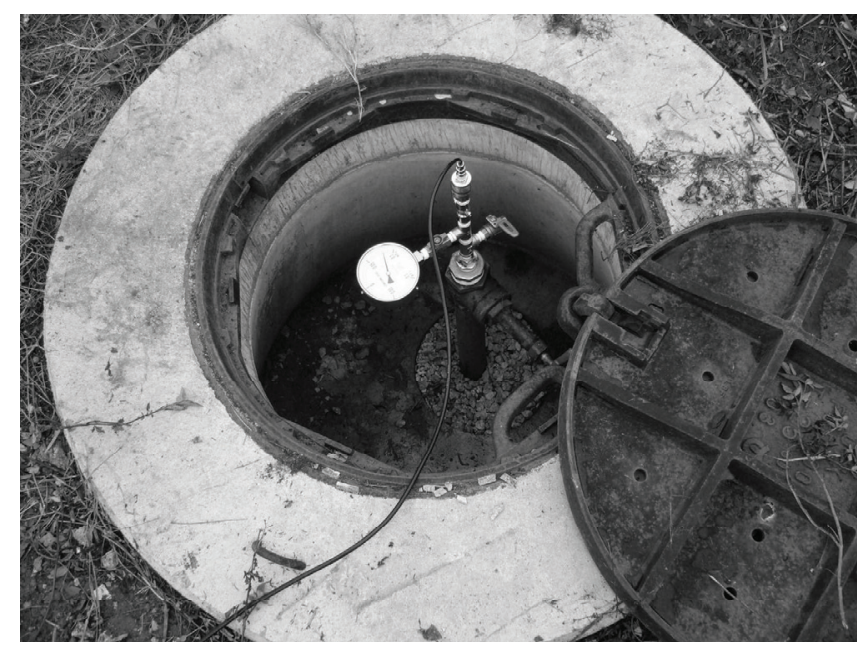

写真 9: 圧力計測 (空気弁)

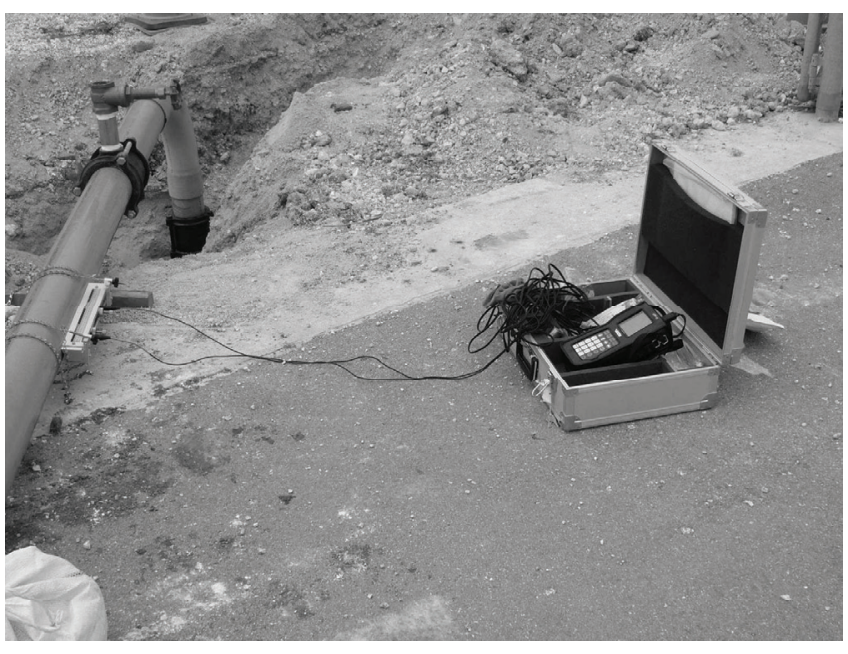

写真 10: 流量計測 (6-1号貯水池)

\section{3 実験内容}

本実験は，6号送水路が通水を停止し，管内の水が始 点と末端から流出し, 封水装置の上流側と(2)地点の下 流側の管内が空になり, 空気が充満している状態から 開始する。最初に，入り口の流入弁と末端の調整弁を 閉鎖し，封水装置の空気孔から充水を行う。この充水 により，管内の空気を十分に排除したことを確認して, 空気孔と空気弁に圧力計を設置する。

その後, 圧力と流量の計測を開始し, 封水装置の電 源を入れ, 流入弁を開操作する。一定時間の経過後, 末端の調整弁を開操作し，サイホン流を生じさせる。実 験条件に応じて，末端の調整弁の開度を調整して，サ イホン流の制御を行う。

実験については，表 3に示すように，調整弁の操作 条件を変更して2回実施した。ケースAでは，末端の調 整弁を一度に全開操作したが，サイホン流が短時間で 切断された。そこで，ケースBでは，サイホン流をできる だけ長く維持するために, 調整弁の設定開度を $5 \%$ およ び10\%の中間開度に絞って実験を行った。実験の結果, 通水開始後において計画流量程度の流量は発生してい るが，10分程度経過すると，ケースAと同様にサイホン 流が切断された。実際の運用では，2〜5時間程度の通 水時間は確保できているので, 調整弁は実験より小さい 開度に設定し, 設計流量以下の小さい流量で運用され ているものと推察される。

表 3: 流入弁・調整弁の操作開始時間

\begin{tabular}{|c|c|c|}
\hline 実験ケース & A & $\mathrm{B}$ \\
\hline 流入弁 $\quad 0 \rightarrow 100 \%$ 開度 & $140 \mathrm{~s}$ & \\
\hline $0 \rightarrow 100 \%$ 開度 & $340 \mathrm{~s}$ & \\
\hline $0 \rightarrow 100 \%$ 開度 & & $380 \mathrm{~s}$ \\
\hline $0 \rightarrow 10 \%$ 開度 & & $1080 \mathrm{~s}$ \\
\hline $10 \rightarrow 5 \%$ 開度 & & $1860 \mathrm{~s}$ \\
\hline
\end{tabular}

\section{5 実験結果}

5.1 サイホン管の圧力と流量の変化

ケースA, Bについて, 上流側の封水装置 (1) と下流側 の空気弁2力所 (2), (3)地点)の圧力標高および流入弁 の直下流における流量の時系列変化を図 5,7 に示す。 
さらに,ケースA, Bの管路圧力標高縦断を図 6,8 に示 す.

\subsection{1 ケースA}

ケースAについては，実験開始時点では，管路の圧力 は(1)地点の空気孔からの充水作業により, 封水装置の 標高EL47.0m程度で静止している。140秒において，入 り口の流入弁を全開した後, 管路の圧力が6-1号貯水池 の水面標高EL42.0m程度に全体的に低下し, 上流部で 負圧状態となっている. その後, 340秒の時点において, 末端の調整弁を全開することにより, サイホン流が発生 し，管路圧力が低下して，動水勾配が形成されている. さらに，350秒において，末端側の (3)地点で管路圧力標 高が計画動水位を下回る結果となっている。

サイホン内が水で満たされている時には, 吸い込み側 の6-1号貯水池の水面には大気圧が作用しているので, 貯水池の水面の圧力がサイホン内の水圧より高くなり, サイホンの水は押されて貯水池には逆流しないため, サ イホン現象が働くことになる。

通水開始後の (1)地点の圧力標高は封水装置地点によ り，EL42.0m程度に維持されているが，400～560秒に かけて，末端水位が計画動水位を大きく下回っており， 動水勾配が急勾配となり, 過剰な流量が発生している. 従って, 管路圧力の均衡が崩れ, 下流側の管路圧力が 大きく低下したため, 標高の高い(2)地点の負圧が増加 し，この間に末端側からサイホン流が崩壊したものと推 察される。その後，560秒付近で管路の圧力が上昇に転 じており，600秒では (3)地点で圧力がほぼゼロになり， 空気が末端部分から管内に入り, この時点でサイホン流 は，崩壊していると考えられる。

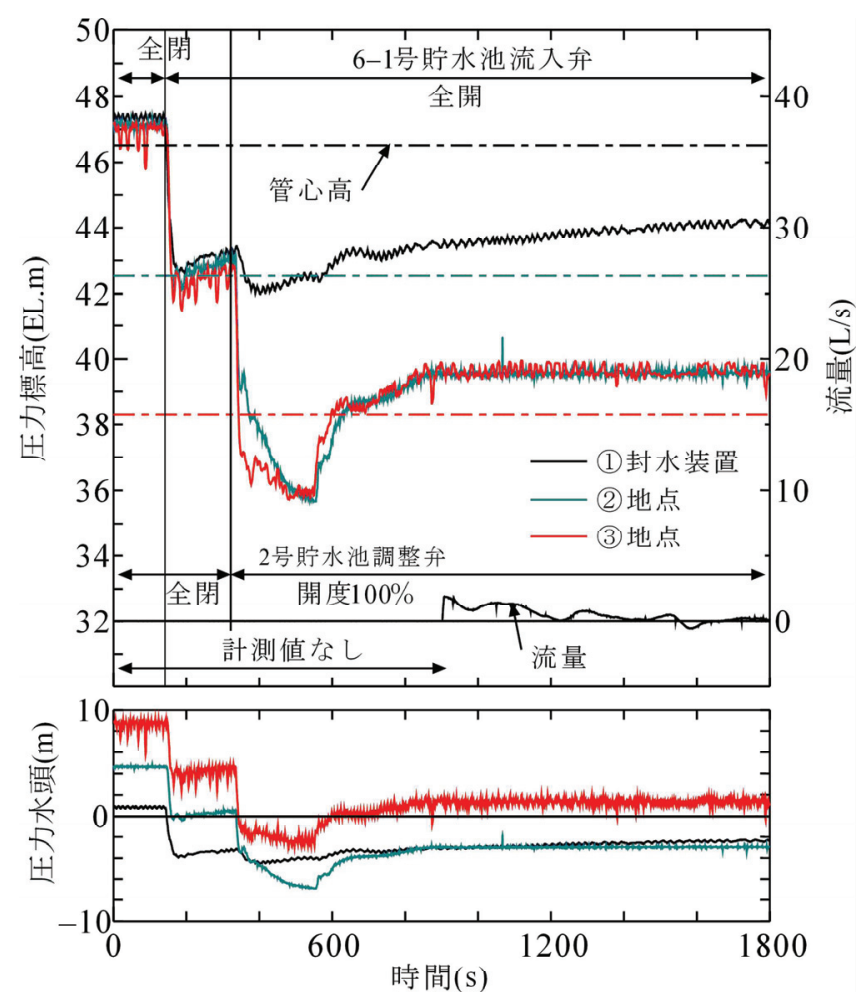

困 5:6号管路の圧力・流量変化図 (ケースA)

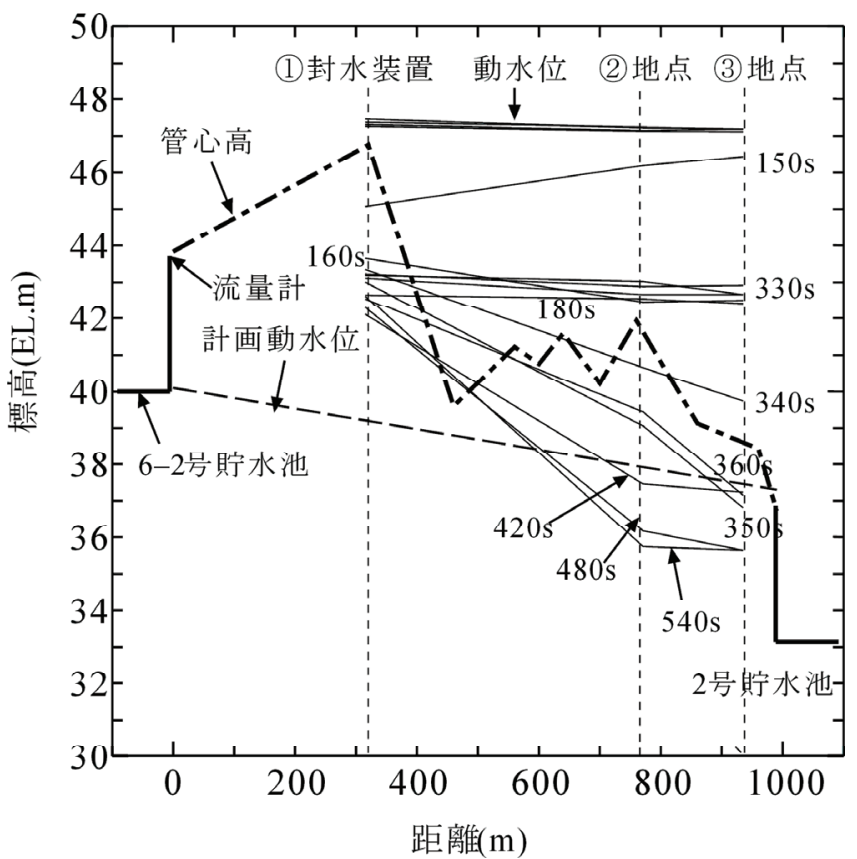

図 6: 圧力標高縦断図(ケースA)

サイホン流が切断された原因は，サイフォンにおいて， 標高の高い地点に進むに連れて管路圧力が低下してい き, 水中に溶け込んでいる空気が気化しやすくなるため, この空気が下流部で標高の高い(2)地点に滞留し, 水の 流れを分断してサイフォンの動きを停止させてしまったも のと考えられる.

また，管路の流量は，計測機器の不具合のため，900 秒までデータが取得できていないが，サイホン流がすで に壊れていると推測される900秒時点において, $1.9 \mathrm{~L} / \mathrm{s}$ の流量が記録されている，従って，340秒で末端弁を開 操作した後, 600秒までの間に, 計画流量に近い流量の サイホン流が過渡的に形成されるが, 安定した通水が 維持されることなく，300秒程度の短時間にサイホン流 の崩壊に至ったと推定される.

1000秒以降は, サイホン流が完全に崩壊し, 流量が 増減しながら漸減して, 通水が停止している。管路の 圧力は，管路内が大気に解放された通水停止状態に徐 々に収れんする. 封水装置地点の圧力標高は, (2)地点 の管心高EL42.0m+1.0m程度になる。 また, (2), (3)地点 の圧力標高は, 未端の管心高EL38.0m+1.0m程度にな っており, (3)地点では, 圧力は $1 \mathrm{~m}$ 程度になっている.

\subsection{2 ケースB}

ケースAにおいて，6号送水路末端の調整弁を一回の操 作で全開にしたため，急激な圧力低下を招き，圧力の 均衡を維持できずに，サイホン流が短時間で消失する結 果となった。そこで，ケースBにおいては，調節弁の弁 開度を段階的に $0 \rightarrow 10 \rightarrow 5 \%$ と変化させる操作を行った。 さらに，ケースAで流量計の不具合により約 900 秒までデ 一タが記録できなかったので, 計測機器の再設定を行 った。

通水停止の状態から，380秒において，流入弁を全開 した後，1000秒までの間は，管路の圧力が全体的に6-1 号貯水池の水面標高EL42.0m程度に低下し, 上流部で 負圧状態となっている。その後，400〜460秒の間，流 入側の6-1号貯水池と封水装置の間で流量 $1.9 \mathrm{~L} / \mathrm{s}$ 程度の 
逆流が生じている，流入弁を閉鎖している状態では，貯 水池とサイホンが遮断されているので, サイホンには充 水後の静水圧が作用しているが，流入弁を開操作した 直後では, 貯水池とサイホンの圧力が連続し, サイホン 部分が負圧になるので，一時的な逆流を生じている。こ の流入弁開操作直後の一時的な逆流現象は, ケースA においても生じていたと推定される。

その後，1080秒の時点で末端の調整弁の開度を $10 \%$ に操作すると，サイホン流が発生し，管路圧力が低下し て, 動水勾配が形成されている. 1000〜 1900秒の間は, 送水路下流側の (2), (3)地点の圧力標高がEL37.0m程度 に低下するが，封水装置地点における圧力標高は，封 水装置が作動して負圧により逸出する空気を水で置換す るため, 通水開始後は, EL $42.0 \mathrm{~m}$ 程度に維持されてい る. 従って, 上流から下流にかけての動水勾配が形成 され，計画流量に近い8.2 5.2L/sの流量が生じており, サイホン流が保持されている. 写真 11に，1380秒にお ける2号貯水池流出口（6号送水路末端）の状況を示す が，サイホン流が形成されているため，送水路末端から 勢いよく流出している.

サイホン流は約1900秒まで継続するが，送水路下流 側の (2), (3)地点の圧力標高の差が小さくなり, 下流側 の動水勾配が減少する結果となった。そのため, 管路 の圧力を維持するために，調整弁の開度を $10 \%$ から $5 \%$ に絞ったが，サイホン流の減衰傾向は続き，6-2号貯水 池流入側（6号送水路始点）においては，1930秒から 流量が発生していない。また，写真 12に，2100秒にお ける2号貯水池流出口の状況を示すが, 末端での流出 は継続しているものの, 流出量はかなり低下している。

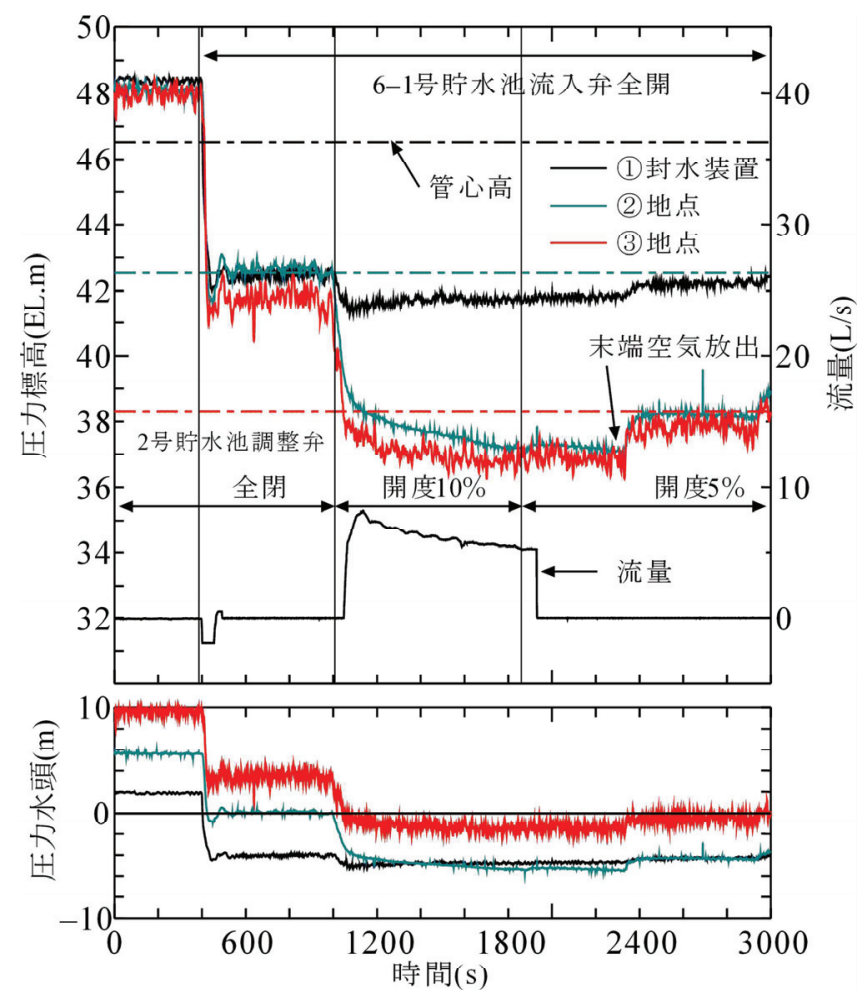

図 7:6号管路の圧力・流量変化図(ケースB)

その後，2460秒において，2号貯水池流出口から，空
気を吹き出す現象が生じ，管路内が大気に解放されて， 空気が連行され，サイホン流が送水路全線で崩壊した。 その結果, 封水装置から上流の管内水および(3)地点よ り下流の管内水は, 貯水池へ流出した. 写真 13 に, 2520 秒における2号貯水池流出口の状況を示すが，末端で空 気を吐きだしている。通水停止時における封水装置地 点の圧力標高は, (2)地点の管心高EL $42.0 \mathrm{~m}$ 程度になっ た。また，(2)，(3)地点の圧力標高は，末端の管心高 EL38.0m程度になり, (3)地点では, 圧力はほぼゼロであ った.

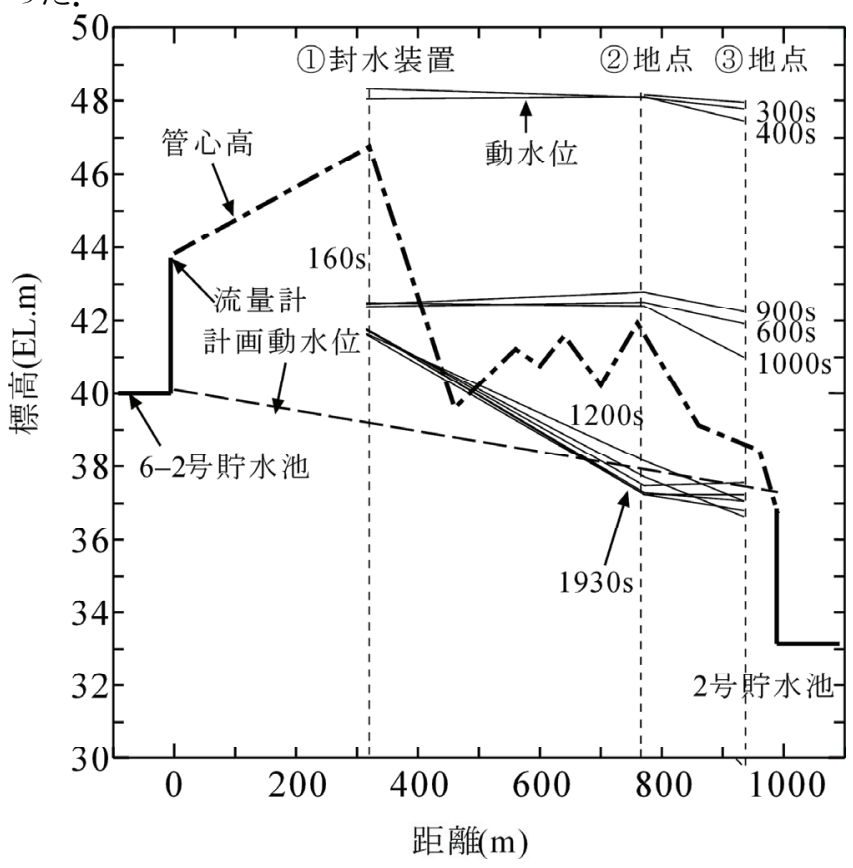

図 8: 圧力標高縦断図(ケースB)

\section{2 封水装置の作動状況}

実験結果からは, 通水停止状態から段階的に通水状態 に移行させれば，サイホン流が形成できることが明らか となっている. 従って, 封水装置の作動機構は, 正常 に稼働しており，逸出する空気を水と置き換えることに より, 封水装置地点の水圧の低下を防ぎ, サイホン上流 部の動水勾配を形成するよう作動していると考えられる。

しかし，サイホン流の維持が長時間継続できず，ヶー スBにおいては10分程度の短時間で崩壊する結果となっ ており, 封水装置の容量不足や送水路の縦断線形など, 他の要因の影響が示唆される.

\section{3 サイホン流が維持できない理由}

通水開始後, サイホン流が形成されるが，2号調整池へ の出口の調整弁を開けて流量が増加すると, 下流部で の圧力低下が大きくなる。 その状況においても，6-1号 調整池から封水装置下流地点までの上流部では, サイ ホン流は形成されているが，送水路の下流部の(2), (3) 地点においては, 流量の増加による圧力の低下が著し くなり，圧力標高が計画動水位を割り込んでいる。

その後, 末端部でサイホン流の切断が発生し，これ が下流側全体へ波及して，やがて送水路全体で，サイ ホン流が崩壊する結果となっている。サイホンの下流部 で圧力標高が計画動水位より一旦低下すると, 自然に 回復することは難しく，短時間でサイホンの崩壊に至る 
可能性が高いと考えられる.

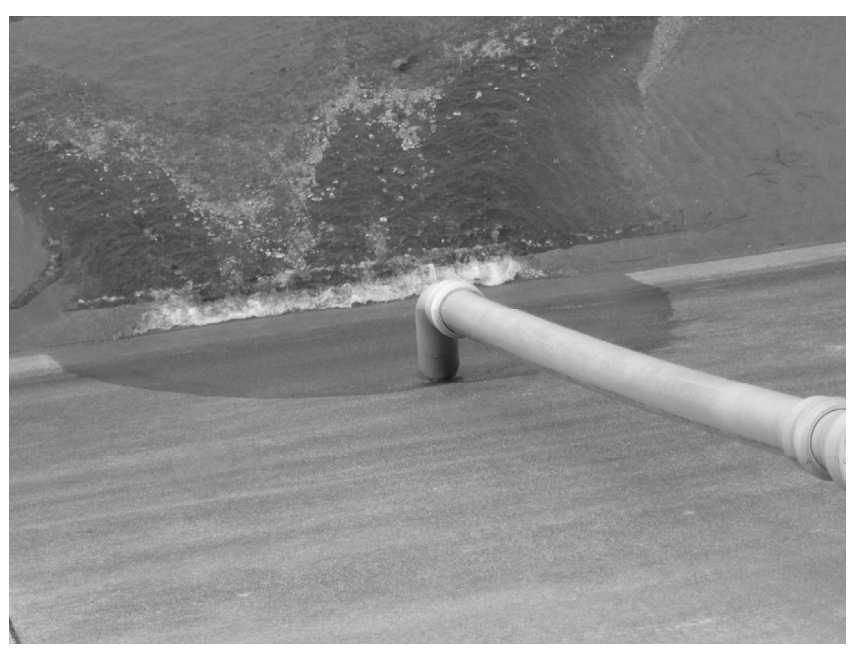

写真 11: 2号貯水池流出口(1380秒)

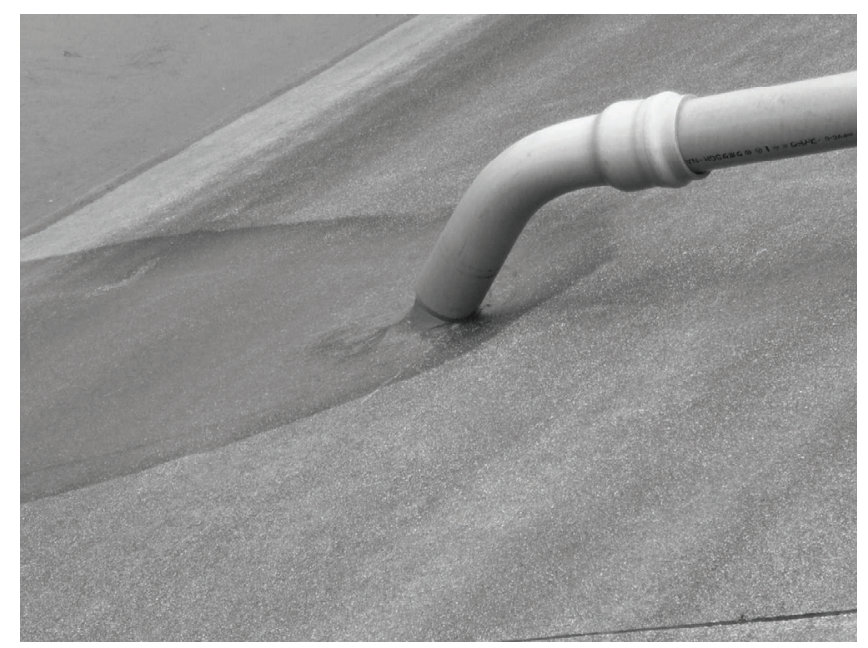

写真 12: 2号貯水池流出口(2100秒)

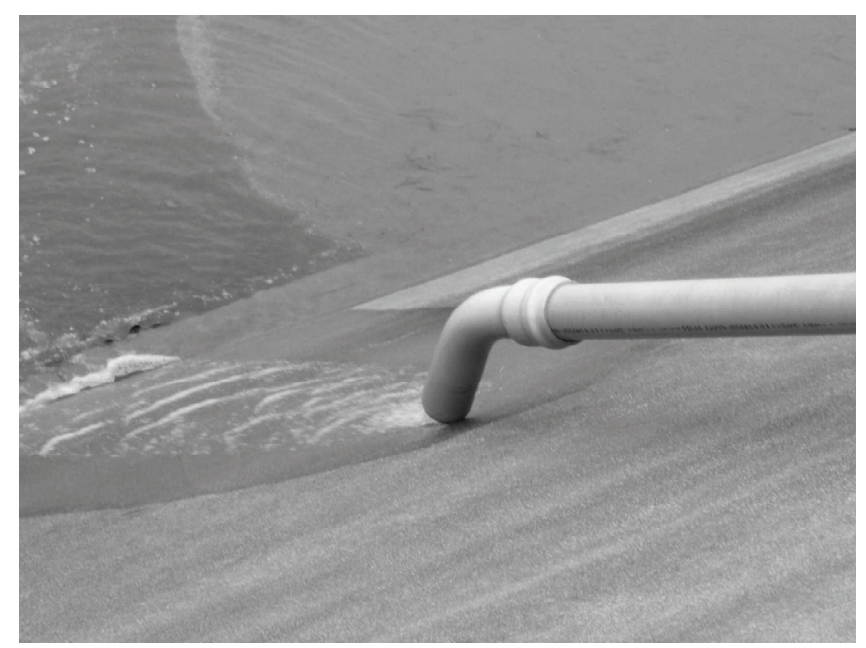

写真 13: 2号貯水池流出口(2520秒)

また，下流側でサイホン流が遮断される原因としては， 6号送水路の下流側の縦断線形が凸になっており, (2)地
点に空気が溜まりやすく, 上流側の封水装置に集まらな い状況となっていると考えられる。(2)地点に溜まった空 気は，初期充水では空気弁(2)を空けることにより強制的 に排除できるが, 通水時には, 負圧となるため通常の 空気弁では排除する方法がない。

従って, 流れにより空気溜まりを最下流へ持って行き, 2 号調整池へ吐き出す以外にはないが，流速が遅いと溜 まった空気を下流へ押し出すことができない。また，逆 に流速が速いと摩擦損失が大きくなり, 負圧が大きくな るので, 空気の分離を促進してしまうことになる。

\section{4 サイホン流の崩壊を避ける方法}

2号貯水池への出口の調整弁については，一度に全開 すると出口で水を引っ張る状況になり，下流部での急激 な水位低下を招くので（ケースA），2号調整池の調整弁 については, サイホン下流側での水位低下を防ぐために, 操作時間を長くかけ, 設定する開度も小さくするように 配慮することが有効であると考えられる（ケースB）。

その他, (2)地点に新たに封水装置を追加設置して, 空気の排除を行う方法が有効であると考えられるが, 補 給水の確保が問題となる。 また，(2)地点でポンプにより 水を注入して, 強制的にサイホンを形成させる方法もあ るが，経済的かつ合理的な選択ではないと考えられる。

\section{5 今後の設計に向けての提案}

一般的にサイホン管は大部分が負圧状態になるが，負 圧状態においては，以下のような現象を生じやすい。

(1)圧力低下により空気が逸出しやすい.

(2)管の継手から空気が混入しやすくなる.

(3)管内で増加した空気は, 負圧により体積が膨張する ので，これが空気溜まりとなって，通水断面を阻害し， サイホン流を切断する要因になりやすい。

従って, 負圧状態で通水するサイホン管においては,

安定した通水を維持するために, 空気の確実な排除は 必要不可久であり, サイホン内で発生する空気を管路の 凸部に集めて，水と置き換えて排除するシステムが，西 山らにより自動空気排除装置（封水装置）として開発さ れている。

著者らは，西山らが開発した封水装置を設置した長 距離サイホン管について, 現地試験を行ったところ, 通 水開始時に形成されているサイホン流が短時間で切断さ れる現象を確認した。これは，サイホン管の構造面また は運用面の理由により, 封水装置による空気溜まりの自 動排除がなされていないものと推察された。

そこで，サイホン管を計画・設計・運用する時には,

以下に示すような配慮・対策がなされることが望ましい。

(1)負圧により逸出する空気を封水装置に集積するため,

管路の縦断線形を一山とし, 封水装置の設置位置は 吸い込み側の貯水池に近接させ，サイホン管の延長 をできるだけ短くなるように路線選定を行う。

(2)初期充水による空気の排除を確実にしたり，管内に 生じた空気塊の移動を容易にするため, 平面線形お よび縦断線形ともに，鋭角な屈曲の設置をできるだけ 避ける計画とする。

(3)理論的な限界值で設計すると，現場で生じる様々な 状況を吸収する余裕がなくなるので, 十分な能力を有 するように配慮する。

(4)初期充水作業の労力を軽減するために, サイホン管 
の中間に制水弁を設置する.

(5)末端弁の操作に時間をかけ，さらに設定開度を小さく するなどの調整を行って, 通水時におけるサイホン管 の下流側水位を維持する.

\section{6 おわりに}

自動空気排除装置 (封水装置) を設置したサイホン管 は，ため池の水を揚水ポンプではなく，サイホンの原理 を用いて，堤防を越えさせて，堤外に運ぶことが出来る ことに特徴がある。サイホン管は, 経済的には非常に有 効であり，島嶼や中山間地などエネルギー事情に恵まれ ない地域では，期待される送水システムであると考えら れる。

このサイホン管をベースにした送水システムについて は, 水理学的に厳密に設計を行い, 施設機能上は問題 ないという結論が得られていても，実際の運用を始める と, 本報告のように, システムが破綻する可能性を否定 できない。このシステムは，外部から駆動エネルギーを 投入して，揚水ポンプを用いて，動水位を強制的に押し 上げるシステムではなく, 自然現象を利用している。従 って，本システムでは，通水時において生じる“ゆらぎ”
を駆動エネルギーではなく, 施設の余裕により吸収でき るよう配慮する必要がある。

今後は，封水装置とサイホン管を組み合わせた送水 システムの運用実績を重ね, 技術的な課題を抽出して, これを検証し, より信頼性の高い送水システムとして構 築することにより，幅広い普及が期待できる.

\section{謝辞}

現地実験では，沖縄県南部農林土木事務所，アジアプ ランニング株式会社の本口晴年氏に多大なご援助をい ただいた。ここに記して厚くお礼申し上げます。

\section{引用文献}

[1] 西山壮一(2000): 溜池の管理 ·整備 ·保全, 農業土木 学会誌, 68(6), pp.579-582.

[2] 姜華英・西山壮一・河野広・南信弘(1994a)：サイホン 内エアポケットの排除と空気逸出量に関する研究, 農 業土木学会論文集, 171, pp.57-66.

[3] 姜華英·西山壮一・河野広・南信弘・満岡重一 (1994b)：サイホン管における自動空気排除装置の開発 と作動特性, 農業土木学会論文集, 173, pp.101-109.

この論文の公開の質疑または討議は2014年6月30日 まで受付けます。 